\title{
The Prevalance and Helminth Infection Degree of Gastrointestinal in Layer Duck Located in Keper and Markolak Kramat Village District of Bangkalan Regency of Bangkalan
}

\section{Prevalensi dan Drajat Infeksi Cacing Saluran Pencernaan Pada Itik Petelur di Dusun Keper dan Dusun Markolak Desa Kramat Kecamatan Bangkalan Kabupaten Bangkalan}

\author{
${ }^{1)}$ Ana Amaliah, ${ }^{2)}$ Indah Norma Triana, ${ }^{3)}$ Poedji Hastutiek , ${ }^{3}$ Setiawan Koesdarto, ${ }^{3)}$ Lucia Tri \\ Suwanti, ${ }^{4}$ Soeharsono \\ ${ }^{1)}$ Student, ${ }^{2}$ Department of Reproduction Veteriner, ${ }^{3}$ Department of Parasitologi Veteriner, ${ }^{4}$ Department \\ of Anatomy Veteriner. Faculty of Veterinary Medicine, Universitas Airlangga.
}

\begin{abstract}
Abstrak
Tujuan dari penelitian ini adalah untuk menentukan prevalensi dan derajat infeksi cacing saluran pencernaan pada itik petelur di dua kondisi lingkungan yang berbeda. Sampel feses diperiksa dengan metode sedimentasi dan metode apung kemudian dilanjutkan dengan menghitung telur cacing per gram tinja dengan metode Mc Master. Hasil menunjukkan bahwa 22,9\% (8/35) itik petelur di Dusun Keper terinfeksi oleh Capillaria sp., dan Echinostoma revolutum, dengan rata-rata derajat infeksi sebsar 52,50 $\pm 41,662$, sedangkan 31,4\% (11/35) itik petelur di Dusun Markolak terinfeksi oleh Capillaria sp., Echinostoma revolutum, dan cacing dari kelas cestoda, dengan rata-rata derajat infeksi sebesar 155,45 $\pm 166,395$. Infeksi bersifat tunggal maupun campuran. Analisis terhadap prevalensi dan derajat infeksi cacing saluran pencernaan itik petelur menunujukkan hasil yang tidak signifikan ( $>>0,05)$ antara Dusun Keper dan Dusun Markolak.
\end{abstract}

Kata kunci: itik petelur, cacing, saluran pencernaan, prevalensi, derajat infeksi

\section{Pendahuluan}

Populasi itik semakin meningkat dari tahun ke tahun sebagai akibat dari naiknya permintaan daging dan telur itik (Imanudin dkk., 2015). Berdasarkan data dari Direktorat Jenderal Peternakan dan Kesehatan Hewan (2016) menyatakan bahwa populasi itik di Indonesia naik dari 44.356.543 ekor pada tahun 2012 menjadi 47.359.722 ekor pada tahun 2016. hal ini menunjukkan bahwa semakin banyak masyarakat yang memelihara itik sebagai usaha sampingan maupun sebagai pendapatan utama.

Usaha dibidang peternakan itik masih terkendala berbagai masalah, salah satunya gangguan kesehatan yang disebabkan oleh infeksi dari endoparasit cacing yang dapat ditemukan pada saluran pencernaan (Pradana dkk., 2015). Penelitian yang dilakukan oleh Paul et al. (2015) di Gombe Nigeria, dari 600 sampel feses itik ditemukan beberapa jenis cacing saluran pencernaan yaitu A. galli, Trichostrongylus tenus, Heterakis gallinarum, Subulura brumpti, Capillaria contorta, C. annulata, Tetrameres fissipina, Raillietina echinobothrida, $R$. tetragona, dan Hymenolepis cantaniana.

Infeksi parasit cacing saluran pencernaan menjadi salah satu masalah besar bagi peternak di Indonesia karena dapat menimbulkan kerugian bagi peternak, dari infeksi ringan yang menyebabkan penurunan produksi yang tak terlihat, hingga infeksi berat yang dapat menyebabkan kematian (Kose et al., 2009). Menurut Sandy dkk. (2015) infeksi cacing saluran pencernaan dapat disebabkan oleh kondisi lingkungan yang memungkinkan berbagai jenis cacing untuk melanjutkan siklus hidupnya.

Berdasarkan survei yang telah dilakukan, kondisi lingkungan Dusun Keper dan Dusun Morkolak Desa Kramat Kecamatan Bangkalan Kabupaten Bangkalan terdapat perbedaan, yaitu 
Dusun Keper yang sebagian besar merupakan lingkungan persawahan, dan Dusun Morkolak yang sebagian besar merupakan lingkungan pertambakan. Sebagai upaya dalam mengurangi kerugian akibat infeksi cacing saluran pencernaan pada itik petelur. maka diperlukan informasi mengenai prevalensi dan derajat infeksi cacing saluran pencernaan pada itik petelur.

\section{Metode Penelitian}

Sampel yang digunakan dalam penelitian ini adalah 35 feses itik petelur yang diambil dari Dusun Keper dan 35 feses itik petelur dari Dusun Markolak. Bahan yang digunakan formalin 10\% dan larutan gula jenuh. Alat yang digunakan ice box, pot sampel, sendok plastik, timbangan, spatula, mortir, gelas plastik, pipet plastik, saringan, gelas ukur, tabung sentrifus, rak tabung, sentrifus, kaca objek, kaca penutup, kertas label, mikroskop, optilab (perangkat digital mikroskop), kamar hitung Mc Master.

Data yang diperoleh dianalisis menggunakan Chi Square Test dan Mann Whitney U-Test dalam program Statistical Product and Service Solution (SPSS) for Windows rel. 23 untuk mengetahui adanya perbedaan prevalensi dan derajat infeksi cacing saluran pencernaan itik petelur di Dusun Keper dan Dusun Morkolak.

\section{Hasil dan Pembahasan}

\section{Prevalensi Cacing Saluran Pencernaan Itik Petelur}

Hasil pemeriksaan terhadap 70 sampel feses itik petelur dari Dusun Keper dan Dusun Markolak ditemukan jenis-jenis telur cacing saluran pencernaan yaitu Capillaria sp., E. revolutum, dan cacing dari kelas cestoda yang dapat dilihat pada Tabel 1 dan Gambar 1.

Tabel 1. Jenis Cacing Saluran Pencernaan Pada Itik Petelur di Dusun Keper dan Dusun Markolak

\begin{tabular}{lcc}
\hline Jenis telur cacing & $\begin{array}{l}\text { Dusun } \\
\text { Keper }\end{array}$ & $\begin{array}{l}\text { Dusun } \\
\text { Markolak }\end{array}$ \\
\hline $\begin{array}{l}\text { Capillaria sp. } \\
\begin{array}{l}\text { E. revolutum } \\
\text { Capillaria sp. dan }\end{array}\end{array}$ & $\mathrm{6}(\mathbf{1 7 , 1} \%)$ & $8(\mathbf{2 2}, 9 \%)$ \\
$\begin{array}{l}\text { E. revolutum } \\
\text { Capillaria sp. dan }\end{array}$ & $\mathbf{2}(5,7 \%)$ & $\mathbf{1}(2,9 \%)$ \\
$\begin{array}{l}\text { cacing kelas } \\
\text { cestoda }\end{array}$ & $\mathrm{o}(\mathrm{o} \%)$ & $\mathbf{1}(2,9 \%)$ \\
\hline
\end{tabular}

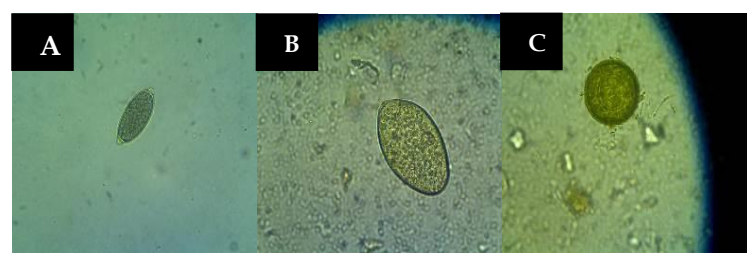

Gambar 1. Jenis cacing saluran pencernaan, A. Telur cacing Capillaria sp. B. Telur cacing E. revolutum, $\mathrm{C}$. Telur cacing cestoda. perbesaran 100x.

Telur Capillaria sp. berukuran 43,3 × 20,5 $\mu \mathrm{m}$, memiliki dinding yang tebal, telur mengandung embrio serta pada kedua ujungnya terdapat bipolar plug. Telur E. revolutum berukuran $73 \times 45$ $\mu \mathrm{m}$, memiliki dinding yang tebal berbentuk oval, telur mengandung embrio dan pada salah satu ujung telur terdapat operculum. Telur cacing cestoda yang ditemukan berdiameter $42,1 \mu \mathrm{m}$, memiliki dinding yang tebal berbentuk bulat, telur mengandung embrio dan di dalam telur terdapat bentukan hexacanth embrio.

Terdapat dua jenis cacing dari kelas cestoda yang memiliki morfologi dan ukuran yang sesuai dengan jenis telur cacing yang ditemukan. Soulsby (1986) menyatakan bahwa telur cacing Raillietina sp. memiliki diameter $25-50 \mu \mathrm{m}$, telur berbentuk bulat dan di dalamnya terdapat bentukan hexacanth embrio, cacing Raillietina sp. memiliki panjang badan mencapai $25 \mathrm{~cm}$. Soulsby (1986) juga mengatakan bahwa telur cacing Hymenolepis sp. memiliki ukuran 30-55 $\times 44-62 \mu \mathrm{m}$, berbentuk bulat dan di dalam telur terdapat bentukan hexacanth embrio, cacing Hymenolepis sp. memiliki panjang badan mencapai 25-40 $\mathrm{mm}$. Berdasarkan kunci identifikasi dari Soulsby (1986) telur cacing cestoda yang ditemukan pada penelitian ini kemungkinan telur Raillietina sp. atau telur Hymenolepis sp.. Perlu dilakukan penelitian lebih lanjut untuk mengetahui jenis cacing cestoda yang menginfeksi itik petelur di Dusun Markolak.

Secara umum infeksi cacing Capillaria sp. terjadi secara campuran dengan cacing $E$. revolutum dan cacing dari kelas cestoda. Cacing Capillaria sp. juga merupakan jenis cacing yang paling banyak ditemukan di kedua kondisi lingkungan tersebut, hal ini dimungkinkan berkaitan dengan siklus hidup cacing Capillaria sp. yang mempunyai siklus hidup tidak langsung dan mempunyai inang antara yaitu cacing tanah 
Eisenia foetida, Allolobophora caliginosa, dan beberapa jenis Lumbricus dan Dendrobaena. Telur keluar bersama dengan feses kemudian termakan oleh cacing tanah, dan unggas terinfeksi karena memakan cacing tanah tersebut (Soulsby, 1986). Itik petelur di Dusun Keper dan Dusun Markolak dipelihara dengan kurang menjaga sanitasi kandang. Kandang yang digunakan adalah ladang kosong serta alas kandangnya merupakan tanah, serta itik dipelihara dengan melepaskannya ke rawa-rawa pada pagi sampai sore hari untuk mencari makan sendiri sehingga memungkinkan itik untuk memakan cacing tanah dan menyebabkan itik terinfeksi oleh cacing saluran pencernaan.

Cacing E. revolutum memiliki siklus hidup tidak langsung dan mempunyai inang antara golongan siput Stagniola palustris, Lymnea stagnalis, dan Lymnea attenuate. Telur akan keluar bersama dengan feses, pada kondisi yang baik, telur akan berkembang menjadi mirasidium, pada hari ketiga kemudian mirasidium melakukan penetrasi ke dalam tubuh inang antara yaitu siput, dalam tubuh siput mirasidium berkembang menjadi serkaria. Serkaria akan mencari inang antara yang lain kemudian menjadi kista. Inang definitif akan terinfeksi jika memakan siput yang mengandung kista (Soulsby, 1986). Beberapa itik petelur di Dusun Keper dan Dusun Markolak tiap pagi hari diberi pakan berupa keong yang didapatkan dari sawah agar kebutuhan protein itik dapat terpenuhi sehingga dapat menghasilkan telur dengan kualitas yang baik, hal ini memungkinkan itik petelur dapat terinfeksi cacing saluran pencernaan karena diberikan pakan berupa keong yang di dalam tubuhnya terdapat serkaria dari E. revolutum.

Cacing cestoda yang menginfeksi itik petelur di Dusun Markolak memiliki siklus hidup tidak langsung dan mempunyai inang antara yaitu Musca domestica, Stomoxys calcitrans dan golongan semut Tetramorium caespitum, $T$. Semilaeve, Pheidole vinelandica, dan $P$. paldulla. Telur yang dikeluarkan bersama feses inang definitif bila termakan oleh inang antara, maka onkosfer akan menetas dan menembus ke organorgan dalam kemudian akan terjadi perkembangan lebih lanjut, onkosfer berkembang menjadi sistiserkoid. Unggas terinfeksi cacing saluran pencernaan karena memakan inang antara yang terinfeksi oleh sistiserkoid cacing cestoda (Soulsby, 1986). Sistem pemeliharaan itik di kedua kondisi lingkungan tersebut kurang menjaga sanitasi kandang serta itik dibiarkan mencari makan sendiri, kemungkinan itik tidak sengaja memakan semut yang di dalam tubuh yang terdapat sistiserkoid cacing cestoda.

Analisis Chi Square dari kedua kondisi lingkungan tersebut terhadap prevalensi cacing saluran pencernaan itik petelur menunjukkan hasil yang tidak signifikan $(\mathrm{p}>0,05)$

\section{Derajat Infeksi Cacing Saluran Pencernaan Itik Petelur}

Pada perhitungan Telur Cacing Per Gram Tinja didapatkan nilai rata-rata sebesar 52,50 \pm 41,662 di Dusun Keper dan 155,45 \pm 166,395 di Dusun Markolak yang dapat dilihat pada Tabel 2.

Tabel 2. Derajat Infeksi Cacing Saluran Pencernaan Itik Petelur

\begin{tabular}{lccc} 
Dusun & Positif & $\begin{array}{l}\text { Mean } \pm \text { Standar } \\
\text { Deviasi }\end{array}$ & $\begin{array}{c}\text { Nilai } \\
\text { p }\end{array}$ \\
\hline $\begin{array}{l}\text { Dusun } \\
\text { Keper }\end{array}$ & 8 & $52,50 \pm 41,662$ & \\
$\begin{array}{l}\text { Dusun } \\
\text { Markolak }\end{array}$ & 11 & $155,45 \pm 166,395$ & 0,321 \\
\hline
\end{tabular}

Hasil dari perhitungan Telur Cacing Per Gram Tinja (TCPGT) di kedua kondisi lingkungan tersebut menunjukkan derajat infeksi cacing saluran pencernaan pada itik petelur tergolong infeksi ringan, hal ini dimungkinkan karena ternak itik lebih tahan terhadap penyakit (Supranianondo dkk., 2011).

Berdasarkan analisis Chi Square menunjukkan hasil yang tidak signifikan ( $>>0,05)$ antara Dusun Keper dan Dusun Markolak terhadap prevalensi cacing saluran pencernaan pada itik petelur, begitu pula dengan analisis Mann Whitney U-Test menunjukkan hasil yang tidak signifikan ( $\mathrm{p}>0,05)$ antara Dusun Keper dan Dusun Markolak terhadap derajat infeksi cacing saluran pencernaan pada itik petelur, hal ini dimungkinkan karena Dusun Keper dan Dusun Markolak termasuk dalam geografis yang sama yaitu dataran rendah yang berada pada ketinggian o-20 mdpl (Unit Pengelola Kegiatan Kamal, 2010), selain itu sistem pemeliharaan itik di Dusun Keper dan Dusun Markolak hampir sama meskipun dengan kondisi lingkungan yang berbeda, itik akan dilepaskan ke rawa-rawa pada pagi sampai sore hari untuk mencari makan sendiri. 


\section{Kesimpulan}

Hasil penelitian menunjukkan bahwa jenis cacing yang menginfeksi saluran pencernaan pada itik petelur di Dusun Keper adalah Capillaria sp. dan $E$. revolutum, dengan prevalensi sebesar 22,9\% dan rata-rata derajat infeksi sebesar 52,50 \pm 41,662, sedangkan jenis cacing yang menginfeksi saluran pencernaan pada itik petelur di Dusun Markolak adalah Capillaria sp., E. revolutum dan cacing dari kelas cestoda, dengan prevalensi 31,4\% dan rata-rata derajat infeksi sebesar 155,45 \pm 166,395 .

\section{Daftar Pustaka}

Imanudin, O., T.B.A. Kurnani, dan S. Wahyuni. 2015. Pengaruh Nisbah C/N Campuran Feses Itik dan Serbuk Gergaji (Albizzia falcata) Terhadap Biomassa Cacing Tanah Lumbricoides rubellus. J. Ilmu Pertanian dan Peternakan. 3(2):36-42

Kementerian Pertanian RI. 2016. Populasi Itik Menurut Provinsi, 2012-2016. //http: www.pertanian.go.id/NAK2016fix/Pop Itik Prop_2016.pdf. [21 Mei 2017].

Kose, M., F. Kircali-Sevimili, E. Kupeli-Kozan, and H. Sert-Cicek. 2009. Prevalence of Gastrointestinal Helminths in Chickens in Afyonkarahisar District, Turkey. Kafkas Univ. Vet. Fak. Derg. 15(3):411-416.

Paul, B.T., J.R. Lawal., E.F. Ejeh., J.J. Ndahi., I.D. Peter., A.M. Bello., and Y. Wakil. 2015. Survey of Helminth Parasites of Free Range Muscovy Ducks (Anas Platyrynchos) Slaughtered in Gombe, North Eastern Nigeria. Int. J. Poult. Sci. 14.

Permatasari, D.A. 2015. Prevalensi dan Derajat Infeksi Cacing Saluran Pencernaan Pada Itik
Jawa (Anas javanicus) di Dua Daerah Geografis Berbeda. [Skripsi]. Fakultas Kedokteran Hewan. Universitas Airlangga. Surabaya.

Pradana, P.P., T. Haryono, dan R. Ambarwati. 2015. Identifikasi Cacing Endoparasit pada Feses Ayam Pedaging dan Ayam Petelur. J. Lentera Bio. 4 (2):119-123.

Samwobo, S.O., N.P. Innocent, I. Oyatogun, O.A. Surakat, and H. Mogaji. 2017. Status of Helminths in Birds Kept in Zoological Park, Abeokuta, Nigeria. J. Of Entomol and Zoo Stud. 5 (6): 390-394.

Sandy, S., S. Sumarni, dan Soeyoko. 2015. Analisis Model Faktor Risiko yang Mempegaruhi Infeksi Kecacingan yang Ditularkan Melalui Tanah Pada Siswa Sekolah Dasar di Distrik Arso Kabupaten Keerom, Papua. Media Litbangkes. 25(1):1-14.

Soulsby, E.J.L. 1986. Helminths, Arthropods, and Protozoa of Domesticated Animals. $7^{\text {th }}$ Ed. British Library Cataloguing in Publication Data. London. 55-56; 61; 99-100; 337 dan 162165

Supranianondo, K., S. Romziah, S. N. Dady, S. Hidanah, H.W. Sunaryo. 2011. Buku Ajar Manajemen Pemeliharaan Ternak Itik. Pusat Penerbitan dan Percetakan Universitas Airlangga. 12.

Unit Pengelola Kegiatan Kamal. 2010. Profil Kabupaten Bangkalan. [20 Juli 2017].

Yulianto, E. 2007. Hubungan Higiene Sanitasi dengan Kejadian Penyakit Cacingan pada Siswa Sekolah Dasar Negeri Rowosari o1 Kecamatan Tembalang Kota Semarang Tahun Ajaran 2006/2007 [Skripsi]. Fakultas Kesahatan Masyarakat. Universitas Negeri Semarang. 